Isyraq, M. • L. Amalia · I. Aisyah

\title{
Pengaruh air kelapa sebagai sitokinin organik dan sukrosa terhadap pertumbuhan protocorm anggrek (Phalaenopsis hybrid MP 253 x F1 $3363(\mathrm{M}))$ in vitro
}

Sari. Sitokinin dan sukrosa dibutuhkan untuk meregenerasi protocorm anggrek. Air kelapa diketahui memiliki kandungan sitokinin sehingga berpotensi dijadikan sebagai sitokinin organik.Percobaan ini bertujuan untuk mempelajari pengaruh konsentrasi air kelapa sebagai sitokinin organik dan sukrosa terhadap pertumbuhan protocorm anggrek. Percobaan ini dilaksanakan di Laboratorium Bioteknologi Tanaman, Fakultas Pertanian Universitas Winaya Mukti, Kecamatan Tanjungsari Kabupaten Sumedang. Percobaan dimulai pada bulan Mei sampai dengan bulan Agustus 2019. Rancangan percobaan yang digunakan adalah rancangan acak kelompok dengan dua faktor dan diulang dua kali. Faktor pertama adalah konsentrasi air kelapa, terdiri dari lima taraf yaitu $0 \mathrm{~mL} \mathrm{~L}^{-1}, 50 \mathrm{mLL}^{-1}, 100 \mathrm{mLL}^{-}$ 1, air kelapa $150 \mathrm{mLL}^{-1}$, dan air kelapa $200 \mathrm{mLL}$.Faktor kedua adalah konsentrasi sukrosa dengan lima taraf,yaitu0 $\mathrm{g} \mathrm{L}^{-1}, 10 \mathrm{~g} \mathrm{~L}^{-1}, 20 \mathrm{~g} \mathrm{~L}^{-1}, 30 \mathrm{~g} \mathrm{~L}^{-1}$ dan $40 \mathrm{~g} \mathrm{~L}^{-1}$. Hasil percobaan menunjukkan terjadi pengaruh interaksi pada pengamatan jumlah daun umur 12 MST dan bobot segar protocorm. Perlakuan air kelapa $50 \mathrm{mLL}^{-1}$ dengan tanpa sukrosa menunjukkan jumlah daun yang paling baik dari perlakuan lainnya. Bobot segar protocorm menunjukkan hasil yang terbaik pada umur 12 MST pada konsentrasi air kelapa $100 \mathrm{mLL}^{-1}$ dengan tanpa sukrosa.

Kata kunci: Air kelapa · In vitro · Protocorm anggrek · Sukrosa

\section{Effect of coconut water as organic cytokinin and sucrose on growth of orchid protocorm (Phalaenopsis hybrid MP 253 x F1 3363 (M)) in vitro}

\begin{abstract}
Cytokinins and sucrose are needed to regenerate orchid protocorms. Coconut water contains cytokinin so that it has the potential to be used as organic cytokinin. This experiment aims to study the effect of coconut water and sucrose concentrations on the growth of orchid protocorms. This experiment was carried out at the Plant Biotechnology Laboratory, Faculty of Agriculture,University Winaya Mukti Tanjungsari, Sumedang. The experiment was conducted from May to August 2019. The experimental design used a randomized block design with two factors and was repeated twice. The first factor was coconut water concentration, consisted by five levels: $0 \mathrm{~mL} \mathrm{~L}^{-1}, 50 \mathrm{mLL}^{-1}, 100 \mathrm{mLL}^{-1}, 150$ $\mathrm{mLL}^{-1}$, and $200 \mathrm{mLL}^{-1}$.The second factor was sucrose concentration, consisted by five levels: $0 \mathrm{~mL} \mathrm{~L}^{-1}$, $10 \mathrm{~g} \mathrm{~L}^{-1}, 20 \mathrm{~g} \mathrm{~L}^{-1}, 30 \mathrm{~g} \mathrm{~L}^{-1}$ and $40 \mathrm{~g} \mathrm{~L}^{-1}$. The results of the experiment showed that there werethe interaction effect of coconut water and sucrose concentrations on the number of leaves and fresh weight of protocorms. Treatment of $50 \mathrm{mLL}^{-1}$ coconut water treatment with no sucrose showed the best number of leaves, compared to other treatments. The best fresh weight of protocorm was givenby treatment of coconut water $100 \mathrm{mLL}^{-1}$ without sucrose.
\end{abstract}

Keywords: Coconut water $\cdot$ In vitro $\cdot$ Orchid protocorm $\cdot$ Sucrose

Diterima : 26 Januari 2021, Disetujui : 10 April 2021, Dipublikasikan : 16 April 2021 doi: https:// doi.org/10.24198/kultivasi.v20i1.29419

Isyraq, M.1 $\cdot$ L. Amalia ${ }^{2}$ I. Aisyah²

${ }^{1}$ Mahasiswa, Fakultas Pertanian Universitas Winaya Mukti

${ }^{2}$ Dosen, Fakultas Pertanian Universitas Winaya Mukti

Korespondensi: israqmuhammad02@gmail.com 


\section{Pendahuluan}

Tanaman anggrek dengan segala keunikannya telah menarik perhatian para botanis yang menyukai tanaman hias sejak dua abad yang lalu. Famili orchidaceae terdiri dari 800 genus dan tidak kurang dari 30.000 spesies,baik yang memiliki nilai komersil maupun anggrekanggrek yangbelum memiliki nilai komersil. Penelitian-penelitian yang intensif, terutama dalam budidaya, difokuskan pada beberapa jenis anggrek yang dewasa ini mempunyai nilai komersial seperti anggrek Phalaenopsis (Gunawan, 2008). Hal ini dapat dilihat melalui keberadaannya di tempat-tempat penting seperti istana, hotel berbintang, pesta besar, dan acara penting lainnya (Setiawan dan Setiawan, 2006). Phalaenopsis merupakan salah satu jenis anggrek yang banyak diminati oleh masyarakat dan konsumen (Zasari et al., 2015). Selain itu Phalaenopsis merupakan tanaman yang menguasai pasar anggrek dunia. Pesona anggrek ini berhasil merambah hingga seluruh Asia, Eropa, bahkan hingga Amerika (Angkasa, 2018).

Anggrek memiliki prospek yang cukup baik dalam dunia bisnis tanaman hias dikarenakan nilai jual yang tinggi dan menjanjikan keuntungan yang besar (Setiawati et al., 2016). Permintaan pasar anggrek terus meningkat dapat dibuktikan bahwa Indonesia masih mengimpor tanaman anggrek dari luar negeri, secara keseluruhan rata-rata nilai impor anggrek selama periode tahun 2015-2019 mengalami peningkatan sebesar $69,06 \%$ setiap tahun dan (BPS, 2019), pada tahun 2014 negara pengimpor anggrek berjumlah 8 negara yaitu Jepang, Singapura, Australia, Taiwan, Arab, Qatar, Malaysia dan Thailand, sedangkan pada tahun 2015 negara pengimpor anggrek hanya 4 negara, seperti Jepang, Singapura, Australia dan Taiwan (Badan Pusat Statistik, 2015).

Perbanyakan in vitro pada anggrek lazim dilakukan untuk memperbanyak tanaman dalam jumlah yang banyak dan waktu yang singkat. Perbanyakan protocorm, yaitu bagian tanaman yang belum terjadi deferensiasi menjadi akar, batang, ataupun daun, dilakukanagar menghasilkan anggrek dengan banyak dan cepat (Abbas, 2011). Sitokinin merupakan salah satu Zat Pengatur Tumbuh yang memiliki peran dalam pembelahan sel yang dibutuhkan untuk perbanyakan protocorm
(Abidin, 1982). Air kelapa didominasi oleh sitokinin, sehingga dapat dijadikan sitokinin organik untuk meregenerasi protocorm anggrek (Letham, 1967). Konsentrasi sukrosa dalam medium cair juga memiliki peran penting dalam regenerasi protocorm (Masnoddin et al., 2016). Oleh karena itu, perlu penelitian mengenai pengaruh air kelapa sebagai sitokinin organik dan sukrosa dalam perbanyakan in vitro anggrek dari protocorm.

\section{Bahan dan Metode}

Penelitian ini dilakukan dengan metode percobaan yang dilaksanakan di Laboratorium Bioteknologi Tanaman Fakultas Pertanian Universitas Winaya Mukti, Desa Gunungmanik, Kecamatan Tanjungsari, Kabupaten Sumedang, Provinsi Jawa Barat pada bulan Mei 2019 sampai dengan bulan Agustus 2019.

Bahan yang digunakan dalam percobaan ini adalah protocorm anggrek Phalaenopsis(MP $253 \times$ F1 $3363(\mathrm{M})$ ) hasil dari penyemaian biji yang telah berumur satu tahun, media Murashige dan Skoog (MS), aquadest, air kelapa muda (dari jenis kelapa hijau), sukrosa (gula pasir berwarna putih yang berasal dari sari tebu), PVP (Poli Venol Pirolidon) sebagai penyerap senyawa venol dan sebagai pencegah browning, PPM (Plant Preservative Mixture) sebagai penghambat tumbuh dan berkembangnya jamur dan bakteri, formalin bubuk, alkohol $70 \%, \mathrm{NaOH} 0,1 \mathrm{~N}, \mathrm{HCl} 0,1 \mathrm{~N}, \mathrm{pH}$ indikator, clorox, sabun pencuci piring, kapas, tissue, plastik, karet gelang,dan kertas label.

Alat yang digunakan dalam percobaan ini adalah botol kaca transparan, tutup botol dari karet, beaker glass, petridish, corong kaca, spatula, pinset, batang pengaduk, pisau, scalpel, sikat botol, sikat cuci, baki plastik, timbangan analitik, panci,kompor, autoclave, enkas, shaker, statif, temometer bola basah dan bola kering, timer automatic, lampu TL (Tubular Lamp) 18 Watt, milimeter blok, alat tulis, penggaris, light meter dan kamera.

Rancangan penelitian yang digunakan adalah Rancangan Acak Lengkap (RAL pola Faktorial) yang terdiri dari 2 faktor dan 2 ulangan, dimana setiap plotterdiri dari dua botol. Rancangan perlakuan terdiri dari 2 faktor, faktor pertama adalah konsentrasi air kelapa (A) dan faktor kedua adalah konsentrasi sukrosa (S). Faktor 
pertama pada percobaan adalah konsentrasi air kelapa, yang terdiri dari tanpa air kelapa $(0 \mathrm{~mL}$ $\left.\mathrm{L}^{-1}\right), 50 \mathrm{ml} \mathrm{L}^{-1}, 100 \mathrm{ml} \mathrm{L}^{-1}, 150 \mathrm{ml} \mathrm{L}^{-1}$ dan $200 \mathrm{ml} \mathrm{L}^{-}$ ${ }^{1}$.Faktor kedua yaitu konsentrasi sukrosa, terdiri dari tanpa sukrosa $\left(0 \mathrm{~g} \mathrm{~L}^{-1}\right), 10 \mathrm{~g} \mathrm{~L}^{-1}, 20 \mathrm{~g} \mathrm{~L}^{-1}, 30 \mathrm{~g}$ $\mathrm{L}^{-1}$ dan $40 \mathrm{~g} \mathrm{~L}^{-1}$.Komposisi media utama yaitu $1 / 2$ MS, PPM 0,5 $\mathrm{ml} \mathrm{L}^{-1}$, dan PVP $0,25 \mathrm{~g} \mathrm{~L}^{-1}$. Pengamatan utama dilakukan pada jumlah protocorm; jumlah daun; jumlah akar; berat segar, ukuran, dan fase protocorm; dan jumlah planlet terbentuk. Pengamatan penunjang dilakukan pada iklim mikro; warna protocorm; persentase kematian protocorm; dan tingkat kontaminasi.

\section{Hasil dan Pembahasan}

Pengamatan penunjang. Pengamatan penunjang merupakan pendukung data dari hasil pengamatan utama yang meliputi suhu, kelembaban, cahaya, warna protocorm, jumlah protocorm mati, dan tingkat kontaminasi

Rata-rata suhu, kelembaban dan cahaya ruangan. Rata-rata suhu ruangan yaitu $25^{\circ} \mathrm{C}$ sementararata-rata kelembaban dalam satu hari yaitu $86,54 \%$. Suhu ruangan berada dalam kisaran suhu optimal pertumbuhan protocorm. Kelembaban mempengaruhi tingkat keberhasilan dalam budidaya anggrek secara in vitro. Budidaya in vitro dikenal memiliki kelembaban udara yang lebih rendah di sekitar planlet (Sasongko et al., 2016).

Total keseluruhan intensitas cahaya dalam satu hari, yaitu 3191,862 FC. Cahaya sangat penting bagi pertumbuhan dan morfogenesis tanaman pada kultur in vitro (Zulkarnain, 2014). Kinetin dan sitokinin yang terlibat dalam pembentukan klorofil dalam kalus akan bekerja apabila terdapat cahaya (Sari et al., 2018).

Warna protocorm. Warna protocorm bervariasi dimana variasi ini memunculkan sembilan warna, diantaranya hijau, hijau kekuningan, hijau putih, hijau kecoklatan, hijau kehitaman, putih transparan, coklat, coklat putih dan coklat kehitaman. Warna protocorm menunjukkan bahwa tingkat atau kandungan klorofil terkandung pada protocorm untuk warna protocorm yang paling baik yaitu pada perlakuan $\mathrm{a}_{2} \mathrm{~S}_{0}$ dengan air kelapa $100 \mathrm{ml} \mathrm{L}^{-1}$ dan tanpa sukrosa dimana protocorm berwarna hijau. Penelitian yang dilakukan oleh Sari et al. (2018), menunjukkan bahwa pada kombinasi 2,4 D dan kinetin pada media MS menyebabkan pembentukan kalus pada tanaman sarang semut dimana warna kalus di semua perawatan berkisar dari kuning dan hijau kekuningan. Variasi warna yang dihasilkan karena terdapat berbagai jenis regulator pertumbuhan. Salah satunya kombinasi antara auksin dan sitokinin menghasilkan warna kalus yang lebih hijau, warna kalus ini disebabkan adanya sitokinin yang berfungsi untuk mempromosikan pembentukan klorofil.

Persentase kematian protocorm. Jumlah protocorm mati yaitu protocorm tidak tumbuh dan berkembangdengan ciri protocorm berubah warna dari yang warnanya hijau berubah menjadi kuning pucat dan pada akhirnya berwarna putih hingga bening. Hal ini menandakan bahwa terjadi peristiwa plasmolisis dimana zat hijau (klorofil) pada protocorm pecah. Pada kalus yang berwarna kuning disebabkan oleh proses degradasi klorofil, kekurangan kinetin, dan konsentrasi kinetin yang rendah. Selain itu, kinetin berperan dalam pembentukan klorofil, yang menyebabkan warna hijau muncul (Sari et al., 2018). Menurut Jung et al. (2013), konsentrasi sukrosa yang tinggi akan memicu penurunan perkembangan dan akan mengalami stress akibat tekanan osmotik. Hasil hidrolisis sukrosa pada konsentrasi yang lebih tinggi akan menghambat perumbuhan dan perkembangan. Protocorm mati dihitung pada akhir pengamatan yaitu pada 12 MST.

Tabel 1. Jumlah dan persentase protocorm mati.

\begin{tabular}{clcc}
\hline No & Keterangan & Jumlah & $\begin{array}{c}\text { Persentase } \\
(\%)\end{array}$ \\
\hline 1 & Protocorm mati Ulangan I & 80 protocorm & 53 \\
2 & Protocorm mati Ulangan II & 45 protocorm & 30 \\
3 & Protocorm hidup Ulangan I & 71 protocorm & 47 \\
4 & Protocorm hidup Ulangan II & 105 protocorm & 70 \\
\hline
\end{tabular}

Tingkat kontaminasi. Tingkat kontaminasi terjadi akibat jamur, jamur dapat menginfeksi dari celah retakan pada botol.Jumlah yang terkontaminasi yaitu 1 botol dengan presentasi kontaminasi $1 \%$.

\section{Pengamatan utama}

Jumlah protocorm. Hasil analisis pengamatan jumlah protocorm pada umur 2, 4, 6, 8, 10 dan 12 minggu setelah tanam (MST) menunjukkan bahwa tidak ada protocorm yang melakukan multiplikasi atau melakukan 
penggandaan, diduga karena pengaruh waktu penelitian yang kurang panjang. Pada perlakuan $\mathrm{a}_{2} \mathrm{~S}_{0}$ menunjukkan bahwa protocorm baru akan melakukan multiplikasi, dimana protocorm sudah mulai memasuki tahap multiplikasi (Gambar 1).

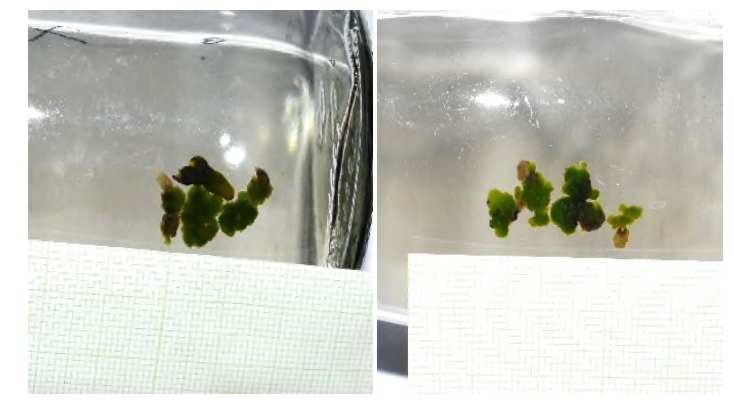

\section{Gambar 1. Perlakuan $\mathrm{a}_{2} \mathrm{~s}_{0}$ umur 12 MST, kiri:} Ulangan I, kanan: Ulangan II.

Jumlah daun. Pada pengamatan jumlah daun, terdapat pengaruh interaksi antara air kelapa dan sukrosa pada umur 4 MST (Tabel 2). Berdasarkan Tabel 2, umur 4 MST menunjukkan adanya interaksi antara konsentrasi air kelapa dan sukrosa terhadap jumlah daun. Pada umur 4 MST, perlakuan air kelapa $100 \mathrm{ml} \mathrm{L}^{-1}$ tanpa sukrosa menunjukkan jumlah daun yang paling baik daripada perlakuan lainnya. Arditti dan Ernst (1993) menyatakan bahwa PLB menghasilkan tunas pada media bebas gula.

Berdasarkan Tabel 3, jumlah daun pada umur 6 MST dipengaruhi oleh adanya pengaruh interaksi antara konsentrasi air kelapa dan sukrosa. Perlakuan air kelapa $50 \mathrm{~mL} \mathrm{~L}^{-1}$ dengan tanpa sukrosa menunjukkan jumlah daun yang paling banyak daripada perlakuan lainnya. Menurut (Baque et al., 2011) $50 \mathrm{ml} \mathrm{L}^{-1}$ air kelapa pada media meningkatkan pertumbuhan tunas. Menurut Tuhuteru et al. (2012), waktu tercepat munculnya kuncup daun pada tanaman anggrek dengan konsentrasi air kelapa $50 \mathrm{~mL} \mathrm{~L}^{-1}$.

Berdasarkan Tabel 4, pengaruh interaksi antara konsentrasi air kelapa dan sukrosa terhadap jumlah daun terjadi pada umur 12 MST. Perlakuan air kelapa $50 \mathrm{~mL} \mathrm{~L}^{-1}$ dengan tanpa sukrosa menunjukkan jumlah daun yang paling baik daripada perlakuan lainnya. Menurut Harahap (2014), menunjukkan bahwa dalam perlakuan MS dan growmore medium, tampak bahwa jumlah daun meningkat dengan memberikan dosis rendah air kelapa (5\% pada media MS dan $10 \%$ pada media growmore).
Media dengan konsentrasi air kelapa $50 \mathrm{ml} \mathrm{L}^{-1}$ merupakan media optimum dalam menghasilkan jumlah daun tertinggi (Tuhuteru et al., 2012).

Perlakuan tidak mempengaruhi jumlah daun yang terbentuk pada umur 2 MST, sedangkan pada umur 8 dan 10 MST konsentrasi air kelapa 100 dan $150 \mathrm{mLL}^{-1}$ menunjukkan lebih baik dibandingkan dengan perlakuan kontrol (Tabel 5). Pada pengamatan jumlah daun umur 2, 8, dan 10 MST, perlakuan sukrosa menunjukkan tidak terdapat perbedaan yang nyata dibandingkan kontrol. Halini diduga pada umur 2, 8, dan 10 MST, sukrosa tidak diperlukan. Protocorm like bodies (PLB) dalam media yang bebas dari pasokan sukrosa menunjukkan pembentukan daun primordia (Julkiflee et al., 2014).

Tabel 5. Pengaruh konsentrasi air kelapa dan sukrosa terhadap jumlah daun pada umur 2, 8 dan 10 MST.

\begin{tabular}{|c|c|c|c|c|c|c|}
\hline \multirow{2}{*}{ Perlakuan } & \multicolumn{6}{|c|}{ Jumlah Daun } \\
\hline & \multicolumn{2}{|c|}{$2 \mathrm{MST}$} & \multicolumn{2}{|c|}{$8 \mathrm{MST}$} & \multicolumn{2}{|c|}{$10 \mathrm{MST}$} \\
\hline \multicolumn{7}{|c|}{ Air Kelapa (A) } \\
\hline $\begin{array}{c}\mathrm{a}_{0} \text { (Tanpa Air } \\
\text { Kelapa })\end{array}$ & 0,20 & $\mathrm{a}$ & 0,00 & $\mathrm{a}$ & 0,00 & $\mathrm{a}$ \\
\hline $\mathrm{a}_{1}\left(50 \mathrm{ml} \mathrm{L}^{-1}\right)$ & 0,10 & $\mathrm{a}$ & 0,30 & $\mathrm{ab}$ & 0,30 & $\mathrm{ab}$ \\
\hline $\mathrm{a}_{2}\left(100 \mathrm{mlL}^{-1}\right)$ & 0,20 & $\mathrm{a}$ & 0,60 & $\mathrm{~b}$ & 0,30 & $a b$ \\
\hline $\mathrm{a}_{3}\left(150 \mathrm{ml} \mathrm{L}^{-1}\right)$ & 0,00 & $\mathrm{a}$ & 0,40 & $a b$ & 0,60 & $\mathrm{~b}$ \\
\hline $\mathrm{a}_{4}\left(200 \mathrm{ml} \mathrm{L}^{-1}\right)$ & 0,00 & $\mathrm{a}$ & 0,35 & $a b$ & 0,25 & $\mathrm{ab}$ \\
\hline \multicolumn{7}{|c|}{ Sukrosa (S) } \\
\hline $\begin{array}{l}\mathrm{s}_{0} \text { (Tanpa } \\
\text { Sukrosa) }\end{array}$ & 0,20 & a & 0,80 & b & 0,50 & a \\
\hline $\mathrm{s}_{1}\left(10 \mathrm{~g} \mathrm{~L}^{-1}\right)$ & 0,10 & $\mathrm{a}$ & 0,35 & $a b$ & 0,45 & $\mathrm{a}$ \\
\hline $\mathrm{s}_{2}\left(20 \mathrm{~g} \mathrm{~L}^{-1}\right)$ & 0,10 & $\mathrm{a}$ & 0,30 & $\mathrm{ab}$ & 0,30 & $\mathrm{a}$ \\
\hline $\mathrm{s}_{3}\left(30 \mathrm{~g} \mathrm{~L}^{-1}\right)$ & 0,00 & $\mathrm{a}$ & 0,00 & $\mathrm{a}$ & 0,00 & $\mathrm{a}$ \\
\hline $\mathrm{s}_{4}\left(40 \mathrm{~g} \mathrm{~L}^{-1}\right)$ & 0,10 & $\mathrm{a}$ & 0,20 & $a b$ & 0,20 & $\mathrm{a}$ \\
\hline
\end{tabular}

Keterangan: Angka rata-rata yang diikuti huruf yang sama menunjukkan berbeda tidak nyata menurut uji jarak berganda Duncan pada taraf nyata $5 \%$.

Jumlah akar. Hasil pengamatan jumlah akar umur 2, 4, 6, 8, 10 dan 12 MST, menunjukkan bahwa tidak terbentuknya akar, maka pada pengamatan ini tidak dilakukan analisis secara statistik. Jumlah akar setelah dilakukannya pengamatan menunjukkan bahwa akar tidak muncul, ini disebabkan tingkat kandungan sitokinin yang tinggi dan auksin yang rendah sehingga menghambat terjadinya pertumbuhan akar (Abbas, 2011). 
Tabel 2. Pengaruh konsentrasi air kelapa dan sukrosa terhadap jumlah daun pada umur 4 MST.

\begin{tabular}{|c|c|c|c|c|c|c|c|c|c|c|}
\hline \multirow{3}{*}{$\begin{array}{c}\text { Air } \\
\text { Kelapa } \\
\mathrm{a}_{0}(\text { Tanpa } \\
\text { Air }\end{array}$} & \multicolumn{10}{|c|}{ Sukrosa } \\
\hline & \multicolumn{2}{|c|}{$\begin{array}{c}\mathrm{s}_{0} \\
\text { (Tanpa } \\
\text { Sukrosa) } \\
\end{array}$} & \multicolumn{2}{|c|}{$\mathrm{s}_{1}\left(10 \mathrm{~g} \mathrm{~L}^{-1}\right)$} & \multicolumn{2}{|c|}{$\mathrm{s}_{2}\left(20 \mathrm{~g} \mathrm{~L}^{-1}\right)$} & \multicolumn{2}{|c|}{$\mathrm{s}_{3}\left(30 \mathrm{~g} \mathrm{~L}^{-1}\right)$} & \multicolumn{2}{|c|}{$\mathrm{s}_{4}\left(40 \mathrm{~g} \mathrm{~L}^{-1}\right.$} \\
\hline & 0,00 & $\mathrm{a}$ & 0,00 & $\mathrm{a}$ & 0,00 & $\mathrm{a}$ & 0,00 & $\mathrm{a}$ & 0,00 & $\mathrm{a}$ \\
\hline Kelapa) & A & & A & & A & & A & & A & \\
\hline $\begin{array}{c}\mathrm{a}_{1}(50 \mathrm{ml} \\
\left.\mathrm{L}^{-1}\right)\end{array}$ & $\begin{array}{c}1,00 \\
\mathrm{~A}\end{array}$ & $a b$ & $\begin{array}{c}0,00 \\
\mathrm{~A}\end{array}$ & $\mathrm{a}$ & $\begin{array}{c}0,00 \\
\mathrm{~A}\end{array}$ & $\mathrm{a}$ & $\begin{array}{c}0,00 \\
\mathrm{~A}\end{array}$ & $\mathrm{a}$ & $\begin{array}{c}0,00 \\
\mathrm{~A}\end{array}$ & $\mathrm{a}$ \\
\hline $\begin{array}{c}\mathrm{a}_{2}(100 \mathrm{ml} \\
\left.\mathrm{L}^{-1}\right)\end{array}$ & $\begin{array}{c}1,00 \\
\mathrm{~B}\end{array}$ & $a b$ & $\begin{array}{c}1,00 \\
\text { B }\end{array}$ & b & $\begin{array}{c}0,00 \\
\mathrm{~A}\end{array}$ & a & $\begin{array}{c}0,00 \\
\mathrm{~A}\end{array}$ & $\mathrm{a}$ & $\begin{array}{c}0,00 \\
\mathrm{~A}\end{array}$ & $\mathrm{a}$ \\
\hline $\begin{array}{c}\mathrm{a}_{3}(150 \mathrm{ml} \\
\left.\mathrm{L}^{-1}\right)\end{array}$ & $\begin{array}{c}0,00 \\
\mathrm{~A}\end{array}$ & $\mathrm{a}$ & $\begin{array}{c}1,00 \\
\text { B }\end{array}$ & b & $\begin{array}{c}0,00 \\
\mathrm{~A}\end{array}$ & $\mathrm{a}$ & $\begin{array}{c}0,00 \\
\mathrm{~A}\end{array}$ & $\mathrm{a}$ & $\begin{array}{c}0,50 \\
\mathrm{AB}\end{array}$ & $\mathrm{a}$ \\
\hline $\begin{array}{c}\mathrm{a}_{4}(200 \mathrm{ml} \\
\left.\mathrm{L}^{-1}\right)\end{array}$ & $\begin{array}{c}1,00 \\
\mathrm{~A}\end{array}$ & $a b$ & $\begin{array}{c}0,00 \\
\mathrm{~A}\end{array}$ & $a b$ & $\begin{array}{c}0,00 \\
\mathrm{~A}\end{array}$ & a & $\begin{array}{c}0,00 \\
\mathrm{~A}\end{array}$ & a & $\begin{array}{c}0,50 \\
\mathrm{~A}\end{array}$ & $\mathrm{a}$ \\
\hline
\end{tabular}

Keterangan: Angka rata-rata yang diikuti huruf kecil yang sama (arah vertikal) dan huruf besar yang sama (arah horizontal) menunjukkan berbeda tidak nyata menurut uji jarak berganda Duncan pada taraf nyata $5 \%$.

Tabel 3. Pengaruh konsentrasi air kelapa dan sukrosa terhadap jumlah daun pada umur 6 MST.

\begin{tabular}{|c|c|c|c|c|c|c|c|c|c|c|}
\hline \multirow{3}{*}{$\begin{array}{c}\text { Air Kelapa } \\
\mathrm{a}_{0}(\text { Tanpa Air } \\
\text { Kelapa) }\end{array}$} & \multicolumn{10}{|c|}{ Sukrosa } \\
\hline & \multicolumn{2}{|c|}{$\begin{array}{l}\mathrm{s}_{0}(\text { Tanpa } \\
\text { Sukrosa) }\end{array}$} & \multicolumn{2}{|c|}{$\mathrm{s}_{1}\left(10 \mathrm{~g} \mathrm{~L}^{-1}\right)$} & \multicolumn{2}{|c|}{$\mathrm{s}_{2}\left(20 \mathrm{~g} \mathrm{~L}^{-1}\right)$} & \multicolumn{2}{|c|}{$\mathrm{s}_{3}\left(30 \mathrm{~g} \mathrm{~L}^{-1}\right)$} & \multicolumn{2}{|c|}{$\mathrm{s}_{4}\left(40 \mathrm{~g} \mathrm{~L}^{-1}\right)$} \\
\hline & $\begin{array}{c}0,00 \\
\text { A }\end{array}$ & $\mathrm{a}$ & $\begin{array}{c}0,00 \\
\mathrm{~A}\end{array}$ & $\mathrm{a}$ & $\begin{array}{c}0,00 \\
\mathrm{~A}\end{array}$ & $\mathrm{a}$ & $\begin{array}{c}0,00 \\
\text { A }\end{array}$ & $\mathrm{a}$ & $\begin{array}{c}0,00 \\
\mathrm{~A}\end{array}$ & $\mathrm{a}$ \\
\hline $\mathrm{a}_{1}\left(50 \mathrm{ml} \mathrm{L}^{-1}\right)$ & $\begin{array}{c}2,50 \\
\text { B }\end{array}$ & d & $\begin{array}{c}0,00 \\
\mathrm{~A}\end{array}$ & a & $\begin{array}{c}0,00 \\
\text { A }\end{array}$ & a & $\begin{array}{c}0,00 \\
\mathrm{~A}\end{array}$ & $\mathrm{a}$ & $\begin{array}{c}0,00 \\
\text { A }\end{array}$ & a \\
\hline $\mathrm{a}_{2}\left(100 \mathrm{ml} \mathrm{L}^{-1}\right)$ & $\begin{array}{c}1,50 \\
\mathrm{~B}\end{array}$ & $\mathrm{~cd}$ & $\begin{array}{c}1,00 \\
\mathrm{~B}\end{array}$ & b & $\begin{array}{c}0,00 \\
\mathrm{~A}\end{array}$ & $\mathrm{a}$ & $\begin{array}{c}0,00 \\
\text { A }\end{array}$ & $\mathrm{a}$ & $\begin{array}{c}0,00 \\
\text { A }\end{array}$ & a \\
\hline $\mathrm{a}_{3}\left(150 \mathrm{ml} \mathrm{L}^{-1}\right)$ & $\begin{array}{c}0,50 \\
\mathrm{~A}\end{array}$ & $a b$ & $\begin{array}{c}1,50 \\
\mathrm{~B}\end{array}$ & b & $\begin{array}{c}0,00 \\
\mathrm{~A}\end{array}$ & a & $\begin{array}{c}0,00 \\
\text { A }\end{array}$ & $\mathrm{a}$ & $\begin{array}{c}0,50 \\
\mathrm{~A}\end{array}$ & $a b$ \\
\hline $\mathrm{a}_{4}\left(200 \mathrm{ml} \mathrm{L}^{-1}\right)$ & $\begin{array}{l}1,00 \\
\text { BC }\end{array}$ & $\mathrm{bc}$ & $\begin{array}{c}0,00 \\
\mathrm{AB}\end{array}$ & $\mathrm{a}$ & $\begin{array}{c}0,00 \\
\text { A }\end{array}$ & a & $\begin{array}{c}0,00 \\
\mathrm{~A}\end{array}$ & a & $\begin{array}{c}1,00 \\
\mathrm{C}\end{array}$ & b \\
\hline
\end{tabular}

Keterangan: Angka rata-rata yang diikuti huruf kecil yang sama (arah vertikal) dan huruf besar yang sama (arah horizontal) menunjukkan berbeda tidak nyata menurut uji jarak berganda Duncan pada taraf nyata $5 \%$.

Tabel 4. Pengaruh konsentrasi air kelapa dan sukrosa terhadap jumlah daun pada umur 12 MST.

\begin{tabular}{|c|c|c|c|c|c|c|c|c|c|c|}
\hline \multirow{4}{*}{$\begin{array}{c}\text { Air Kelapa } \\
\mathrm{a}_{0} \text { (Tanpa Air } \\
\text { Kelapa) }\end{array}$} & \multicolumn{10}{|c|}{ Sukrosa } \\
\hline & \multicolumn{2}{|c|}{$\begin{array}{l}\mathrm{s}_{0} \text { (Tanpa } \\
\text { Sukrosa) }\end{array}$} & \multicolumn{2}{|c|}{$\mathrm{s}_{1}\left(10 \mathrm{~g} \mathrm{~L}^{-1}\right)$} & \multicolumn{2}{|c|}{$\mathrm{s}_{2}\left(20 \mathrm{~g} \mathrm{~L}^{-1}\right)$} & \multicolumn{2}{|c|}{$\mathrm{s}_{3}\left(30 \mathrm{~g} \mathrm{~L}^{-1}\right)$} & \multicolumn{2}{|c|}{$\mathrm{s}_{4}\left(40 \mathrm{~g} \mathrm{~L}^{-1}\right)$} \\
\hline & 0,00 & $\mathrm{a}$ & 0,00 & a & 0,00 & $\mathrm{a}$ & 0,00 & $\mathrm{~A}$ & 0,00 & $\mathrm{a}$ \\
\hline & A & & A & & A & & A & & A & \\
\hline $\mathrm{a}_{1}\left(50 \mathrm{ml} \mathrm{L}^{-1}\right)$ & $\begin{array}{c}2,00 \\
B\end{array}$ & b & $\begin{array}{c}0,00 \\
\mathrm{~A}\end{array}$ & $\mathrm{a}$ & $\begin{array}{c}0,00 \\
\mathrm{~A}\end{array}$ & $\mathrm{a}$ & $\begin{array}{c}0,00 \\
\mathrm{~A}\end{array}$ & A & $\begin{array}{c}0,00 \\
\mathrm{~A}\end{array}$ & $\mathrm{a}$ \\
\hline $\mathrm{a}_{2}\left(\begin{array}{c}100 \mathrm{ml} \mathrm{L}^{-} \\
\text {- }\end{array}\right.$ & $\begin{array}{c}0,00 \\
\mathrm{~A}\end{array}$ & a & $\begin{array}{c}0,50 \\
\mathrm{~A}\end{array}$ & $\mathrm{a}$ & $\begin{array}{c}1,00 \\
\mathrm{~A}\end{array}$ & $\mathrm{a}$ & $\begin{array}{c}0,00 \\
\mathrm{~A}\end{array}$ & A & $\begin{array}{c}0,50 \\
\mathrm{~A}\end{array}$ & $\mathrm{a}$ \\
\hline $\mathrm{a}_{3}(\underset{1}{150} \mathrm{ml} \mathrm{L}$ & $\begin{array}{c}1,00 \\
\mathrm{~A}\end{array}$ & $a b$ & $\begin{array}{c}0,00 \\
\mathrm{~A}\end{array}$ & a & $\begin{array}{c}0,00 \\
\mathrm{~A}\end{array}$ & $\mathrm{a}$ & $\begin{array}{c}0,00 \\
\mathrm{~A}\end{array}$ & A & $\begin{array}{c}1,00 \\
\mathrm{~A}\end{array}$ & a \\
\hline $\mathrm{a}_{4}\left(200 \mathrm{ml} \mathrm{L}^{-}\right.$ & 0,50 & $\mathrm{ab}$ & 0,00 & a & 0,00 & $\mathrm{a}$ & 0,00 & A & 0,00 & a \\
\hline
\end{tabular}

Keterangan: Angka rata-rata yang diikuti huruf kecil yang sama (arah vertikal) dan huruf besar yang sama (arah horizontal) menunjukkan berbeda tidak nyata menurut uji jarak berganda Duncan pada taraf nyata $5 \%$.

Ukuran protocorm. Berdasarkan Tabel 6, menunjukkan bahwa tidak terjadi pengaruh interaksi antara perlakuan air kelapa dan sukrosa terhadap ukuran protocorm 4, 8, 10, dan 12 MST. Pada perlakuan air kelapa, ukuran protocorm umur 4 MST tidak menunjukkan perbedaan antar perlakuan, sedangkan pada umur 8, 10 dan 12
MST dengan taraf air kelapa $50 \mathrm{mLL}^{-1}$ menunjukkan ukuran protocorm yang lebih baik dibandingkan dengan perlakuan kontrol, namun tidak berbeda nyata dengan konsentrasi yang lain. Perlakuan tanpa sukrosa menunjukkan tidak terdapat perbedaan yang nyata dengan perlakuan berbagai konsentrasi sukrosa.Hal ini menunjukkan bahwa pada rentang waktu 8, 10, dan 12 MST, sukrosa tidak diperlukan. Ini disebabkan tanpa adanya penambahan perlakuan sukrosa, tidak terjadinya penghambatan dalam bertambah besarnya ukuran protocorm.

Tabel 6. Pengaruh konsentrasi air kelapa dan sukrosa terhadap ukuran protocorm $(\mathrm{mm})$ pada umur 4, 8, 10 dan 12 MST.

\begin{tabular}{|c|c|c|c|c|c|c|c|c|}
\hline \multirow{2}{*}{ Perlakuan } & \multicolumn{8}{|c|}{ Ukuran Protocorm $(\mathrm{mm})$} \\
\hline & \multicolumn{2}{|l|}{$4 \mathrm{MST}$} & \multicolumn{2}{|c|}{8 MST } & \multicolumn{2}{|c|}{$10 \mathrm{MST}$} & \multicolumn{2}{|c|}{$12 \mathrm{MST}$} \\
\hline \multicolumn{9}{|c|}{ Air Kelapa (A) } \\
\hline \multicolumn{9}{|l|}{$\mathrm{a}_{0}$ (Tanpa Air } \\
\hline Kelapa) & 4,87 & $\mathrm{a}$ & 3,89 & a & 3,83 & $\mathrm{a}$ & 3,98 & a \\
\hline $\mathrm{a}_{1}\left(50 \mathrm{ml} \mathrm{L}^{-1}\right)$ & 5,06 & a & 5,35 & $\mathrm{~b}$ & 5,58 & b & 5,55 & b \\
\hline $\mathrm{a}_{2}\left(100 \mathrm{ml} \mathrm{L}^{-1}\right)$ & 5,20 & $\mathrm{a}$ & 5,79 & b & 5,65 & b & 6,04 & b \\
\hline $\mathrm{a}_{3}\left(150 \mathrm{ml} \mathrm{L}^{-1}\right)$ & 5,02 & $\mathrm{a}$ & 5,08 & b & 5,52 & b & 5,79 & b \\
\hline $\mathrm{a}_{4}\left(200 \mathrm{ml} \mathrm{L}^{-1}\right)$ & 4,53 & $\mathrm{a}$ & 4,72 & $\mathrm{~b}$ & 4,76 & $\mathrm{~b}$ & 4,92 & $\mathrm{~b}$ \\
\hline \multicolumn{9}{|c|}{ Sukrosa (S) } \\
\hline \multicolumn{9}{|l|}{$\mathrm{s}_{0}$ (Tanpa } \\
\hline Sukrosa) & 5,07 & a & 5,21 & a & 5,33 & a & 5,63 & a \\
\hline $\mathrm{s}_{1}\left(10 \mathrm{~g} \mathrm{~L}^{-1}\right)$ & 4,63 & $\mathrm{a}$ & 4,42 & a & 4,48 & $\mathrm{a}$ & 4,78 & a \\
\hline $\mathrm{s}_{2}\left(20 \mathrm{~g} \mathrm{~L}^{-1}\right)$ & 5,14 & $\mathrm{a}$ & 5,15 & $\mathrm{a}$ & 5,34 & $\mathrm{a}$ & 5,61 & $\mathrm{a}$ \\
\hline $\mathrm{S}_{3}\left(30 \mathrm{~g} \mathrm{~L}^{-1}\right)$ & 4,91 & a & 5,04 & a & 4,84 & a & 5,14 & a \\
\hline $\mathrm{s}_{4}\left(40 \mathrm{~g} \mathrm{~L}^{-1}\right)$ & 4,91 & $\mathrm{a}$ & 5,01 & $\mathrm{a}$ & 5,36 & $\mathrm{a}$ & 5,10 & $\mathrm{a}$ \\
\hline
\end{tabular}

Berdasarkan Tabel 7, ukuran protocorm pada umur 2 MST dipengaruhi pengaruh interaksi antara konsentrasi air kelapa dan sukrosa. Perlakuan air kelapa $100 \mathrm{mLL}^{-1}$ dengan sukrosa $40 \mathrm{~g} \mathrm{~L}^{-1}$ menunjukkan yang terbaik pada ukuran protocorm umur 2 MST.

Tabel 7. Pengaruh konsentrasi air kelapa dan sukrosa terhadap ukuran protocorm pada umur 2 MST.

\begin{tabular}{|c|c|c|c|c|c|c|c|c|c|c|}
\hline \multirow{4}{*}{$\begin{array}{c}\text { Air Kelapa } \\
a_{0}(\text { Tanpa } \\
\text { Air Kelapa) }\end{array}$} & \multicolumn{10}{|c|}{ Sukrosa } \\
\hline & \multicolumn{2}{|c|}{$\begin{array}{l}\text { so(Tanpa } \\
\text { Sukrosa) }\end{array}$} & \multicolumn{2}{|c|}{$\mathrm{s}_{1}\left(10 \mathrm{~g} \mathrm{~L}^{-1}\right)$} & \multicolumn{2}{|c|}{$\mathrm{s}_{2}\left(20 \mathrm{~g} \mathrm{~L}^{-1}\right)$} & \multicolumn{2}{|c|}{$\mathrm{s}_{3}\left(30 \mathrm{~g} \mathrm{~L}^{-1}\right)$} & \multicolumn{2}{|c|}{$\mathrm{s}_{4}\left(40 \mathrm{~g} \mathrm{~L}^{-1}\right)$} \\
\hline & 5,00 & $\mathrm{a}$ & 4,53 & a & 5,75 & a & 5,13 & a & 4,00 & a \\
\hline & A & & A & & A & & A & & A & \\
\hline $\mathrm{a}_{1}\left(50 \mathrm{ml} \mathrm{L}^{-1}\right)$ & $\begin{array}{c}4,25 \\
\mathrm{~A}\end{array}$ & $\mathrm{a}$ & $\begin{array}{c}4,78 \\
\mathrm{~A}\end{array}$ & $\mathrm{a}$ & $\begin{array}{c}4,79 \\
\mathrm{~A}\end{array}$ & $\mathrm{a}$ & $\begin{array}{c}3,67 \\
\mathrm{~A}\end{array}$ & $\mathrm{a}$ & $\begin{array}{c}3,96 \\
\mathrm{~A}\end{array}$ & $\mathrm{a}$ \\
\hline$\underset{1}{\mathrm{a}_{2}\left(100 \mathrm{ml} \mathrm{L}^{-}\right.}$ & $\begin{array}{c}4,92 \\
\mathrm{AB}\end{array}$ & $\mathrm{a}$ & $\begin{array}{c}4,08 \\
\mathrm{~A}\end{array}$ & $\mathrm{a}$ & $\begin{array}{c}5,05 \\
\mathrm{AB}\end{array}$ & a & $\begin{array}{c}4,47 \\
\mathrm{~A}\end{array}$ & $\mathrm{a}$ & $\begin{array}{c}6,50 \\
\mathrm{~B}\end{array}$ & b \\
\hline $\mathrm{a}_{3}(\underset{1}{1})$ & $\begin{array}{c}5,17 \\
\mathrm{~A}\end{array}$ & a & $\begin{array}{c}4,80 \\
\mathrm{~A}\end{array}$ & $\mathrm{a}$ & $\begin{array}{c}4,92 \\
\mathrm{~A}\end{array}$ & $\mathrm{a}$ & $\begin{array}{c}5,00 \\
\mathrm{~A}\end{array}$ & $\mathrm{a}$ & $\begin{array}{c}4,27 \\
\text { A }\end{array}$ & $\mathrm{a}$ \\
\hline $\begin{array}{c}\mathrm{a}_{4}(200 \mathrm{ml} \mathrm{L} \\
\left.{ }^{1}\right)\end{array}$ & $\begin{array}{c}4,79 \\
\mathrm{~A}\end{array}$ & $\mathrm{a}$ & $\begin{array}{c}4,65 \\
\mathrm{~A}\end{array}$ & $\mathrm{a}$ & $\begin{array}{c}5,13 \\
\mathrm{~A}\end{array}$ & $\mathrm{a}$ & $\begin{array}{c}4,58 \\
\mathrm{~A}\end{array}$ & $\mathrm{a}$ & $\begin{array}{c}5,35 \\
\mathrm{~A}\end{array}$ & $a b$ \\
\hline
\end{tabular}

Keterangan: Angka rata-rata yang diikuti huruf kecil yang sama (arah vertikal) dan huruf besar yang sama (arah horizontal) menunjukkan berbeda tidak nyata menurut uji jarak berganda Duncan pada taraf nyata $5 \%$.

Menurut Arditti dan Ernst (1993), 10\% air kelapa dan 0,5 ppm 2,4 Dichlorophenoxyacetic acid $(2,4$ D) memberikan pertumbuhan kalus 
yang terbaik pada media yang mengandung glukosa tetapi bebas dari auksin dan garam media yang mengandung $10 \%$ air kelapa. Regenerasi wujud terjadi pada larutan media yang mengandung sukrosa, 10\% air kelapa, serta tidak adanya auksin. Karbohidrat berfungsi sebagai sumber energi dalam medium, sementara air kelapa dan sukrosa juga bertindak untuk melengkapi tekanan osmotikum dalam kultur sel tanaman dan perkembangan protocorm secara signifikan (Huh et al., 2016). Prorocorm sebagai hasil in vitro memiliki kemampuan untuk berfotosintesis yang rendah, sehingga membutuhkan tambahan gula untuk tumbuh (Sasongko et al., 2016).

Tabel 8. Pengaruh konsentrasi air kelapa dan sukrosa terhadap ukuran protocorm pada umur 6 MST.

\begin{tabular}{|c|c|c|c|c|c|c|c|c|c|c|}
\hline \multirow{3}{*}{$\begin{array}{c}\text { Air Kelapa } \\
\mathrm{a}_{0}\end{array}$} & \multicolumn{10}{|c|}{ Sukrosa } \\
\hline & \multicolumn{2}{|c|}{$\begin{array}{l}\text { So(Tanpa } \\
\text { Sukrosa) } \\
\end{array}$} & \multicolumn{2}{|c|}{$\mathrm{s}_{1}\left(10 \mathrm{~g} \mathrm{~L}^{-1}\right)$} & \multicolumn{2}{|c|}{$\mathrm{s}_{2}\left(20 \mathrm{~g} \mathrm{~L}^{-1}\right)$} & \multicolumn{2}{|c|}{$\mathrm{s}_{3}\left(30 \mathrm{~g} \mathrm{~L}^{-1}\right)$} & \multicolumn{2}{|c|}{$\mathrm{s}_{4}\left(40 \mathrm{~g} \mathrm{~L}^{-1}\right)$} \\
\hline & 5,13 & $\mathrm{a}$ & 4,40 & $a$ & 5,00 & $\mathrm{a}$ & 5,25 & $\mathrm{a}$ & 4,17 & $a$ \\
\hline $\begin{array}{l}\text { (Tanpa Air } \\
\text { Kelapa) }\end{array}$ & A & & A & & A & & A & & A & \\
\hline $\mathrm{a}_{1}\left(50 \mathrm{ml} \mathrm{L}^{-1}\right)$ & $\begin{array}{c}5,27 \\
\mathrm{~A}\end{array}$ & $\mathrm{a}$ & $\begin{array}{c}5,75 \\
\mathrm{~A}\end{array}$ & $\mathrm{a}$ & $\begin{array}{c}5,29 \\
\text { A }\end{array}$ & $\mathrm{a}$ & $\begin{array}{c}5,58 \\
\mathrm{~A}\end{array}$ & $\mathrm{a}$ & $\begin{array}{c}5,33 \\
\mathrm{~A}\end{array}$ & $a b$ \\
\hline $\mathrm{a}_{2}(\underset{1}{1})$ & $\begin{array}{c}5,88 \\
\mathrm{~A}\end{array}$ & $\mathrm{a}$ & $\begin{array}{c}5,42 \\
\mathrm{~A}\end{array}$ & $\mathrm{a}$ & $\begin{array}{c}5,22 \\
\mathrm{~A}\end{array}$ & $\mathrm{a}$ & $\begin{array}{c}5,20 \\
\mathrm{~A}\end{array}$ & $\mathrm{a}$ & $\begin{array}{c}6,50 \\
\mathrm{~A}\end{array}$ & b \\
\hline $\mathrm{a}_{3}\left(\underset{1}{150} \mathrm{ml} \mathrm{L}^{-}\right.$ & $\begin{array}{c}5,83 \\
\mathrm{~B}\end{array}$ & $\mathrm{a}$ & $\begin{array}{c}5,37 \\
\mathrm{AB}\end{array}$ & $\mathrm{a}$ & $\begin{array}{c}5,50 \\
\mathrm{AB}\end{array}$ & $\mathrm{a}$ & $\begin{array}{c}5,40 \\
\mathrm{AB}\end{array}$ & $\mathrm{a}$ & $\begin{array}{c}4,17 \\
\mathrm{~A}\end{array}$ & $\mathrm{a}$ \\
\hline $\begin{array}{c}\mathrm{a}_{4}\left(\begin{array}{c}200 \\
{ }^{1}\end{array}\right) \\
\mathrm{ml} \mathrm{L}^{-}\end{array}$ & $\begin{array}{c}5,21 \\
\mathrm{~A}\end{array}$ & $\mathrm{a}$ & $\begin{array}{c}4,65 \\
\mathrm{~A}\end{array}$ & $\mathrm{a}$ & $\begin{array}{c}5,42 \\
\mathrm{~A}\end{array}$ & a & $\begin{array}{c}4,50 \\
\mathrm{~A}\end{array}$ & $\mathrm{a}$ & $\begin{array}{c}5,40 \\
\mathrm{~A}\end{array}$ & $\mathrm{ab}$ \\
\hline
\end{tabular}

Keterangan: Angka rata-rata yang diikuti huruf kecil yang sama (arah vertikal) dan huruf besar yang sama (arah horizontal) menunjukkan berbeda tidak nyata menurut uji jarak berganda Duncan pada taraf nyata $5 \%$.

Berdasarkan Tabel 8, ukuran protocorm pada umur 6 MST dipengaruhi interaksi antara konsentrasi air kelapa dan sukrosa. Perlakuan air kelapa $150 \mathrm{mLL}^{-1}$ dengan tanpa sukrosa menunjukkan ukuran protocorm yang baik pula. Menurut Mondal et al. (2012), ketika air kelapa ditambahkan dalam medium, terjadi peningkatan yang signifikan dalam eksplan yang menunjukkan regenerasi tunas sebanyak $75 \%$ pada pengunaan air kelapa sebanyak $100 \mathrm{mLL}^{-1}$ dan $74 \%$ pada pengunaan air kelapa sebanyak 150 mLL:

Bobot segar protocorm. Hasil analisis statistik bobot segar protocorm pada 12 MST tersaji pada Tabel 9.

Berdasarkan Tabel 9, bobot segar protocorm pada umur 12 MST dipengaruhi adanya interaksi antara konsentrasi air kelapa dan sukrosa. Perlakuan air kelapa $100 \mathrm{mLL}^{-1}$ dengan tanpa sukrosa menunjukkan hasil yang terbaik pada bobot segar protocorm umur $12 \mathrm{MST}$, namun tidak berbeda nyata dengan 50, 150, dan $200 \mathrm{~mL}$ air kelapa tanpa sukrosa. Pada perlakuan sukrosa $10 \mathrm{~g} \mathrm{~L}^{-1}$, semua konsentrasi air kelapa tidak berbeda nyata.

Tabel 9. Pengaruh konsentrasi air kelapa dan sukrosa terhadap bobot segar protocorm pada umur 12 MST.

\begin{tabular}{|c|c|c|c|c|c|c|c|c|c|c|}
\hline \multirow{3}{*}{$\begin{array}{l}\text { Air Kelapa } \\
\mathrm{a}_{0}(\text { Tanpa Air }\end{array}$} & \multicolumn{10}{|c|}{ Sukrosa } \\
\hline & \multicolumn{2}{|c|}{$\begin{array}{l}\mathrm{s}_{0}(\text { Tanpa } \\
\text { Sukrosa) }\end{array}$} & \multicolumn{2}{|c|}{$\mathrm{s}_{1}\left(10 \mathrm{~g} \mathrm{~L}^{-1}\right)$} & \multicolumn{2}{|c|}{$\mathrm{s}_{2}\left(20 \mathrm{~g} \mathrm{~L}^{-1}\right)$} & \multicolumn{2}{|c|}{$\mathrm{S}_{3}\left(30 \mathrm{~g} \mathrm{~L}^{-1}\right)$} & \multicolumn{2}{|c|}{$\mathrm{s}_{4}\left(40 \mathrm{~g} \mathrm{~L}^{-1}\right)$} \\
\hline & 0,009 & $\mathrm{a}$ & 0,011 & $\mathrm{a}$ & 0,017 & a & 0,019 & $\mathrm{a}$ & 0,009 & $\mathrm{a}$ \\
\hline Kelapa) & A & & A & & A & & A & & A & \\
\hline $\mathrm{a}_{1}\left(50 \mathrm{ml} \mathrm{L}^{-1}\right)$ & $\begin{array}{c}0,033 \\
\mathrm{~A}\end{array}$ & b & $\begin{array}{c}0,037 \\
\mathrm{~A}\end{array}$ & b & $\begin{array}{c}0,015 \\
\mathrm{~A}\end{array}$ & $\mathrm{a}$ & $\begin{array}{c}0,018 \\
\mathrm{~A}\end{array}$ & $\mathrm{a}$ & $\begin{array}{c}0,020 \\
\mathrm{~A}\end{array}$ & $\mathrm{a}$ \\
\hline $\mathrm{a}_{2}\left(100 \mathrm{ml} \mathrm{L}^{-1}\right)$ & $\begin{array}{c}0,066 \\
\text { B }\end{array}$ & b & $\begin{array}{c}0,019 \\
\text { A }\end{array}$ & $a b$ & $\begin{array}{c}0,027 \\
\text { A }\end{array}$ & a & $\begin{array}{c}0,023 \\
\text { A }\end{array}$ & $\mathrm{a}$ & $\begin{array}{c}0,020 \\
\mathrm{~A}\end{array}$ & $\mathrm{a}$ \\
\hline $\mathrm{a}_{3}\left(150 \mathrm{ml} \mathrm{L}^{-1}\right)$ & $\begin{array}{c}0,035 \\
\text { A }\end{array}$ & b & $\begin{array}{c}0,034 \\
\text { A }\end{array}$ & b & $\begin{array}{c}0,028 \\
\mathrm{~A}\end{array}$ & a & $\begin{array}{c}0,020 \\
\mathrm{~A}\end{array}$ & a & $\begin{array}{c}0,018 \\
\text { A }\end{array}$ & a \\
\hline $\mathrm{a}_{4}\left(200 \mathrm{ml} \mathrm{L}^{-1}\right)$ & $\begin{array}{c}0,035 \\
\mathrm{~A}\end{array}$ & b & $\begin{array}{c}0,007 \\
\text { A }\end{array}$ & $a b$ & $\begin{array}{c}0,020 \\
\mathrm{~A}\end{array}$ & $\mathrm{a}$ & $\begin{array}{c}0,022 \\
\mathrm{~A}\end{array}$ & a & $\begin{array}{c}0,023 \\
\mathrm{~A}\end{array}$ & a \\
\hline
\end{tabular}

An: Angka rata-rata yang diikuti huruf kecil yang dan huruf besar yang sama (arah horizontal) menunjukkan berbeda tidak nyata menurut uji jarak berganda Duncan pada taraf nyata $5 \%$.

Pada perlakuan $\mathrm{a}_{2} \mathrm{~S}_{0}$ umur 12 MST (Gambar 1), menunjukkan bahwa ukuran protocorm yang cukup besar yang mana mempengaruhi hasil dari penimbangan bobot segarprotocorm yaitu pada perlakuan air kelapa $100 \mathrm{mLL}^{-1}$ dan tanpa sukrosa. Halini sejalan dengan pendapat Zasari et al. (2015), bahwa penambahan air kelapa 100 $\mathrm{mLL}^{-1}$ dalam media $1 / 2$ MS menunjukkan hasil terbaik salah satunya bobot basah. Protocrom like bodies (PLB) menghasilkan tunas pada media yang terbebas dari gula (Ardittidan Ernst, 1993), serta pembentukan protocorm lebih cepat (Jung et al., 2013). Hal tersebut dapat terjadi dikarenakan air kelapa dengan konsentrasi $50 \mathrm{mLL}^{-1}$ menunjukkan pertumbuhan protocorm yang baik menurut Romeida et al.(2018).

Fase protocorm. Fase protocorm bermacammacam mulai dari fase oktan, globular, awal hati, hati, torpedo bahkan ada pula yang mencapai dewasa, yaitu pada perlakuan $\mathrm{a}_{1} \mathrm{~s}_{0}$ ulangan 2, bahwa protocorm sudah menunjukkan adanya daun. Halini sesuai dengan pendapat Zulkarnain (2014).

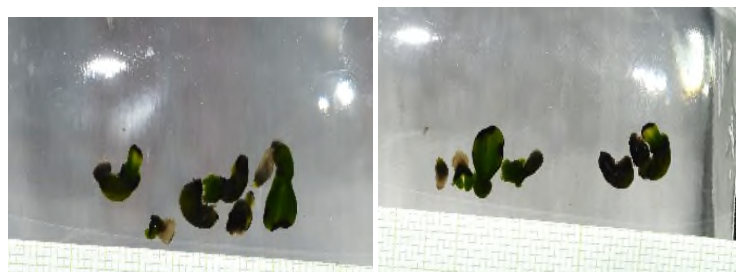

Gambar 2. Perlakuan $a_{1} s_{0}$, kiri umur: 10 MST, kanan Umur: 12 MST.

Jumlah planlet terbentuk. Planlet merupakan tanaman dewasa dimana bagian tanaman sudah tidak berbentuk protocorm atau 
bagian tanaman yang belum dapat dideferensiasi mana bagian akar, daun dan batang. Pada penelitian ini protocorm umur 12 MST tidak menunjukkan adanya perubahan dari protocorm kearah planlet atau tanaman sempurna yang memiliki akar, batang, namun ada beberapa perlakuan yang memunculkan daun.Pada penelitian ini tidak ada yang menunjukkan perubahan secara signifikan dimana protocorm mengalami fase organogenesis atau tanaman sempurna, dari bentuk protocorm hingga menjadi planlet atau tanaman yang memiliki kondisi tubuh yang lengkap seperti akar, batang dan daunZulkarnain (2014).Hal ini memerlukan penelitian lebih lanjut.

\section{Kesimpulan}

Berdasarkan hasil percobaan mengenai pengaruh konsentrasi air kelapa dan sukrosa terjadi interaksi pada pengamatan jumlah daun umur 12 MST pada perlakuan air kelapa 50 mLL-1 $^{-1}$ dengan tanpa sukrosa menunjukkan jumlah daun yang paling baik dari perlakuan lainnya. Bobot segarprotocorm menunjukkan hasil yang terbaik pada umur 12 MST di pengaruhi adanya interaksi antara konsentrasi air kelapa $100 \mathrm{mLL}^{-1}$ dengan tanpa sukrosa.

\section{Daftar Pustaka}

Abbas, B. 2011. Prinsip Dasar Teknik Kultur Jaringan. Alfabeta, Bandung.

Abidin, Z. 1982. Dasar-dasar Pengetahuan Tentang Zat Pengatur Tumbuh. Angkasa, Bandung.

Angkasa, S. 2018. Cara Agar Anggrek Bulan Rajin Berbunga. Trubus Swadaya, Jakarta.

Arditti, J dan Ernst, R. 1993. Micropropagation of Orchids. Department of Developmental and Cell Biology. University of California, irvine California.

Badan, S.P. 2015. Statistik Tanaman Hias Statistics of Ornamental Plants Indonesia. Jakarta.

Baque, M.A., Y.-K. Shin, T. Elshmari, E.-J. Lee, and K.-Y. Paek. 2011. Effect of Light Quality, Sucrose and Coconut Water Concentration on The Micropropagation of Calanthe Hibrids ('Bukduseong' $\times$ 'Hyesung' and 'Chunkwang' $\times$ 'Hyesung').
Aust. J. Crop Sci. 5: 1247-1254.

Gunawan, L.. 2008. Budidaya Anggrek. Edisi Revi. Penebar Swadaya, Jakarta.

Huh, Y.S., J.K. Lee, S.Y. Nam, E.Y. Hong, K.Y. Paek, et al. 2016. Effects of altering medium strength and sucrose concentration on in vitro germination and seedling growth of Cypripedium macranthos Sw. J. Plant Biotechnol. 43(1): 132-137. doi: 10.5010/ JPB.2016.43.1.132.

Julkiflee, A.L., J. Uddain, and S. Subramaniam. 2014. Efficient micropropagation of Dendrobium sonia-28 for rapid PLBs proliferation. Emirates J. Food Agric. 26(6): 545-551. doi: 10.9755/ejfa.v26i6.18020.

Jung, W.P., S.. Chin, C.Y. Lee, and F. Chen. 2013. Effect of sucrose concentration and seed maturity on in vitro germination of Dendrobium nobile hybrids. doi: 10.1007/ s10725-013-9856-x.

Letham, D.S. 1967. Cytokinins from Zea mays (S. Contributions, editor). Canberra, Australia.

Masnoddin, M., R. Repin, and Z. Abd. 2016. Micropropagation of an endangered Borneo Orchid, Paphiopedilum rothschildianum Callus using Temporary Immersion Bioreactor System. 34(2): 161-171. doi: 10.14456/thaidoa-agres.2016.12.

Mondal, S., M.K. Ahirwar, M.K. Singh, P. Singh, and R.P. Singh. 2012. Effect of coconut water and ascorbic acid on shoot regeneration in banana variety Dwarf Cavendish. ASIAN J. Hortic. 7(2): 416-419.

Romeida, A., Supanjani, and S.S. Sinaga. 2018. Low-Cost Media for in vitro Multiplication and Development of Protocorm Like Bodies (PLBs) of Eulophia graminea Orchid. Int. J. Adv. Sci. Eng. Inf. Technol. 8: 78-84.

Salisbury, F.B., and C.. Ross. 1995. Fisiologi Tumbuhan. Jilid Tiga. Perkembangan Tumbuhan dan Fisiologi Lingkungan (Edisi Keempat) (N. Sofia, editor). Bahasa Ind. ITB, Bandung.

Sari, Y.P., E. Kusumawatu, C. Saleh, W. Kustiawan, and S. Sukartingsih. 2018. Effect of sucrose and plant growth regulators on callogenesis and preliminary secondary metabolic of different explant Myrmecodia tuberosa. Nusant. Biosci. 10(3): 183-192. doi: 10.13057/nusbiosci/ n100309.

Sasongko, A.B., A. Fatumi, and A. Indrianto. 2016. The Growth Improvement of Grammatophyllum scriptum (Lindl.) Bl. In Vitro Plantlet using Photoautotrophic 
Micropropagation System. Indones. J. Biotechnol. 21(2): 109. doi: 10.22146/ ijbiotech.27167.

Setiawan, H. dan Setiawan, L. 2006. Merawat Phalaenopsis. Penebar Swadaya, Jakarta.

Setiawati, T., M. Nurzaman, E.S. Rosmiati, and G.G. Pitaloka. 2016. Pertumbuhan Tunas Anggrek Dendrobium sp. Menggunakan Kombinasi Benzyl Amino Purin (BAP) dengan Ekstrak Bahan Organik pada Media Vacin and Went (VW). J. Pro-Life 3(3): 143152.
Tuhuteru, S.M.L., S.H.. Hehanussa, and Raharjo. 2012. Pertumbuhan dan Perkembangan Anggrek Dendrobium anosmum pada Media Kultur In Vitro Dengan Beberapa Konsentrasi Air Kelapa. Agrologia 1: 1-12.

Zasari, M., Yusnita, and S. O. 2015. Pengaruh Pemberian Berbagai Jenis Adenda Dalam Media 1/2 MS Terhadap Pertumbuhan Seedling Anggrek Phalaenopsis In Vitro. 8(1): 31-36.

Zulkarnain. 2014. Kultur Jaringan Tanaman. 1st ed. PT Bumi Aksara, Jakarta. 